\title{
Vicarious Experience by Modeling and Comparing of Children Stories from Czech and Madura Island: Behavior and Moral Perspectives
}

\author{
Imron Wakhid Harits, Stefan Chudy, Alena Opletalova, Dana Vicherkova \\ Faculty of Education, University of Palacky, Olomouc, Czech Republic \\ Email: imronwakhidharits@gmail.com
}

Received 6 March 2015; accepted 11 May 2015; published 14 May 2015

Copyright (C 2015 by authors and Scientific Research Publishing Inc.

This work is licensed under the Creative Commons Attribution International License (CC BY). http://creativecommons.org/licenses/by/4.0/

(c) (i) Open Access

\begin{abstract}
Children learn from their environment according to what they see around them. If they get the positive input, they will behave positively, but if they get the negative input, consequently they will imitate the negative behavior. Therefore, choosing the right media such as TV program and reading materials for children needs many considerations, because of their characteristics in learning. One of the suggested reading materials for the children is children stories. This research is aimed to observe and investigate the role of stories for the children in shaping the children behavior and internalizing the moral values. This is a salient thing to introduce the children stories including the traditional stories for the children due to its content of moral messages and education in such stories. The observational learning or social learning theory from Bandura is used to undermine the multi aspects of moral education that are found in the children stories. It is because Bandura theory figures out the process of modeling and imitation from one to another using the observational process. While the traditional children stories will be taken from some stories from the two different countries, between Madura traditional stories from Indonesia and Czech traditional stories. The choice of two different countries is expected to represent three different cultural perspectives, mainly Asia and or Eastern and Western cultural perspective. The stories that are chosen are the 3 popular traditional stories from Czech written by the most outstanding Bohemian woman writer, Bozena Nemcova, and three traditional stories from Madura Island. All of these children stories are very popular for their own community. Thus, the ethnography approach is also needed to do the research. The understanding of the different cultural backgrounds among the stories from three different countries is very important to get the better comprehending in the stories, especially the relationship among the stories and children behavior and moral perspectives.
\end{abstract}


Keywords

Modeling, Traditional Children Stories, Ethnography Approach, Children Behavior, Moral Values

\section{Introduction}

It was amazing and amusing when in my childhood listening the story of Sang Kancil and Its Series (the mousedeer), which was the most popular children stories in my childhood. This story was undocumented and it was told orally from the parents to their children. This traditional story shows the traditional setting of culture, custom, and nature. The jungle, the river and the farm field characterized the setting of story, while the crocodile, snail, tiger, elephant, farmer, and the mousedeer itself became the characters in the story. It depicts the influence of culture and nature to the traditional children stories. Sang Kancil was the well-known story for children, which was mostly told every day before sleeping by the parents. Consequently, in the following day, the children discussion in the school will talk about this story, discussing the smartness of the mousedeer, laughing at the elephant, crocodile, and tiger stupidity, chatting how the mousedeer can cheat them and so forth. The simple discussion of the children dealing with the story is always about the amusement, funny, and entertaining simple topics.

Attending the children listened the stories will emerge two kinds of possibilities, firstly they will be laughing and happy, and perhaps secondly, they will yawn as the reaction of their boredom. It is natural response and honest expression from the children from the entire world in acquaintance with the interesting and uninteresting of the stories that they have heard. Certainly, it will come to the same idea that all children like the nice stories. The term "nice" here is in the context of the children milieu, and thus the stories for the children should make them happy or they are the joyful stories. The aim of children stories firstly is how to make an enjoyment for them. It is a very important notion about the children literature, because the children world must be pleasure and taken away from the pressure (Grenby, 2004). Since its aim is enjoyment, the children stories should consider the appropriate themes in line with the childhood. The choosing of the themes is the substance way in children stories due to its consideration in education and moral teaching. Thus, according to Hakemulder (2000), the stories not only should rely on the exciting theme and plot, but also should contain the education and moral teaching for the children.

Meanwhile, in relation with the theme, the children stories must consider the development of the children age. Referred to the definition of children literature, Lynch-Brown \& Tomlinson (1999) defined children literature as good-quality trade books for children from birth to adolescence, covering topics of relevance, and interest to children of those ages, through prose and poetry, fiction and non-fiction (p. 2). Many children stories are scattered around and they can be easily found today, but not all of such children stories are suitable for the children mental development. In this case, the theme including the content of the stories should become the salient consideration to choose the best stories according to the level of an age. For example, the theme is a truly essential problem in the way of choosing the stories for children. The themes in the children stories are usually the childhood world and problems, such as telling their new toys and pets, talking the scary things like the ghost, their excitement of the new friends and school, and so forth. Or, the themes can also be the common themes that are loved by the children, like the imaginative themes about big dragon, giant lizard, and dinosaur till the super hero. The sentimental problems and other rough themes are inappropriate for the children, because such themes are not engaging with their world and ages, like the suicide, love stories, and so forth. Further, Hunt (2003) gives the more detailed definition of the children stories and books. Children's books are different from adults' books: they are written for a different audience, with different skills, different needs, and different ways of reading (p. 3).

The educated theme and the moral teaching content of children stories are usually the reflection of custom, culture, and belief from one society. Consequently, even though the moral standard is universal, their way to accomplish their idea will be different among others. The cultural history of the society will affect the children stories a lot. For instance, the society with its history of the royal family life will dominate the children stories from one generation to the next generation; thus, in the next phase, the children stories will tell about the noble life of the king, queen, prince, and princess as well as their characters. The theme will deliver the ideas of the 
royal family problem such as the good princess, the wise king, the cruel queen, the brave prince, and so forth. On the other hand, the children stories that are not rooted from the royal society environment will take away from the noble, kingdom, and palace themes. The ordinary people in this case will be the heroes and heroines in the children stories (Horihan, 1997). The hard-working farmer, the tough young man, the smart boy and girl, the diligent woman, the patient lady and so on will usually become the favorite themes for the children stories sourced from the common society. Then, related with the educated themes, the children stories have to teach the young generation with kindnesses such as giving motivation, teaching and sharing knowledge, learning the world, giving experiences, and teaching the kindness.

During the content of the children stories must educate the society because of its lodge of the local wisdom; thus, it is important to consider these children stories as the resource packs to bring up and shape the characteristics of the children through the role model of the good characters in the stories (Meautia, 2009). The children tend to learn from their social environment and try to look for their role model to behave (Pressley \& McCormick, 1997). The children also learn a lot from their experiences. Ironically, today many TV programs and children story books make bad effects on the children, because the TV and book publishers tend to their business orientation rather than the education. As a result, the TV programs are not selective for their program for children. To anticipate such problem, the selective children stories can be given as the alternative for shaping the children character. The method of modeling in observational learning is used to give the solution to have an appropriate role model for children behavior.

\section{Theoretical Framework}

\subsection{Constructivism}

The constructivism, which uses the learner's environment which influences them, is one way to solve such problem in poetry class. In constructivist point of view, learners' environment will be the focus in the learning process together with their experiences, and knowledge. "... An activity and development of a learner gets into the center of attention" (Juvova, Chudy, Neumeister, Plischke, \& Kvintova, 2014: p. 2). Constructivism itself can be defined as learner conceptions of knowledge are derived from a meaning-making search in which learners engage in a process of constructing individual interpretations of their experiences (Applefield, Huber, \& Moallem, 2001: p. 6). Then, Desforges looks the constructivism from the different point of view, he observes the constructivism from the process of mental in human's mind. He suggests that constructivist should identifying learner's existing schemata and then arranging experiences that challenge those schemata and that provoke the construction of more advanced intellectual structures (p. 71). Its intellectual structure relates with the students schemata or their prior knowledge for one topic of discussion and develop the new knowledge on it. Thus, the use of prior knowledge (schemata) will support the students while they attempt to solve the problem in learning process. The teacher can help his/her students to recall their prior knowledge to comprehend one topic in the classroom. Byrness (1996), "Schemata serve several functions in learning: categorizing, remembering, comprehending and problem solving”. First, schemata or prior knowledge links categorize our experiences more efficiently for processing. This categorization of information facilitates the processes of remembrance (recall), and comprehension (understanding), all of which make problem solving more productive"

According to the definition of constructivism above, there are two main stream of constructivism principles: 1) knowledge is not passively received but actively built up by the cognizing subject; 2) the function of cognition is adaptive and serves the organization of the experiential world, not the discovery of ontological reality (Husen \& Postlethweite, 1989: p. 114). For the first principle, it needs the mutual interrelation between the learner and the teacher. Both of them must be active in the learning process, and the teacher is as the facilitator to trigger and explore to optimize learners' competence. Here, the learners do not only react to experience, but they reflect on it, and theorize it, developing mental structures or schemata for understanding it (Desforges, 2000: p. 69). While, the second principle, in learning process it requires the contextual experience and social environment that support the learning process to get the aim of learning.

\subsection{Social or Observational Learning Approach}

This theory tries to combine between behaviorism, cognitive development theory, and its environmental influences. Based on this theory, the people basically observe other people behavior, and they store it in their mind, 
then they will perform the new behavior. This theory is happened in the social context, the people learn another, by modeling and imitation. This is also called observational theory, because in modeling and imitating, there is happened the process of observation from one to another. Bandura is the proponent of this theory, according to Bandura in (Pressley \& McCormick, 1997) learning would be exceedingly laborious, not to mention hazardous, if people had to rely solely on the effects of their own actions to inform them what to do. Fortunately, most human behaviour is learned observationally through modeling: from observing others one forms an idea of how new behaviours are performed, and on later occasions this coded information serves as a guide for action. Social learning theory explains human behavior in terms of continuous reciprocal interaction between cognitive, behavioural, an environmental influences. There are four components in line with the process of underlying observational learning namely: Attention, Retention, Motor Reproduction and Motivation.

Firstly is an attention, it suggests that observers cannot learn unless they pay attention to what's happening around them. This process is influenced by characteristics of the model, such as how much one likes or identifies with the model, and by characteristics of the observer, such as the observer's expectations or level of emotional arousal. Furthermore is retention, it defines that observers must not only recognize the observed behavior but also remember it at some later time. This process depends on the observer's ability to code or structure the information in an easily remembered form or to mentally or physically rehearse the model's actions. The next is production in this case; observers must be physically and/intellectually capable of producing the act. In many cases the observer possesses the necessary responses. But sometimes reproducing the model's actions may involve skills the observer has not yet acquired. It is one thing to carefully watch a circus juggler, but it is quite another to go home and repeat those acts. At last is motivation it is generally observers will perform the act only if they have some motivation or reason to do so. The presence of reinforcement or punishment, either to the model or directly to the observer, becomes most important in this process.

\section{Method of Research: Ethnography}

During this paper discuss the traditional children stories from two different societies; the ethnography approach is the appropriate to use to probe some cultural aspects and their implications (Reeves et al., 2008). The ethnography approach usage in teaching comparative stories searches the textual analysis (close reading) informed by contextual knowledge, such as social history. Then, Educational ethnographies according to Tellez \& Waxman in Marczyk et al. (2005), in particular, have allowed researchers to explore nuances of learners and learning environments and explain their work in "thick descriptions", allowing their readers to gain an appreciation for the complexity of language learning under varied conditions and contexts.

\section{Result and Discussion}

\subsection{Cultural and Custom in Traditional Stories: Czech and Madura Island Brief History}

The traditional stories are rooted and originated from the values of the one society; it is a kind of long tradition in line with their custom, belief, nature, moral, and culture. Certainly, the traditional stories are much affected by their cultural, natural, and custom setting where these stories are originated. The difference of the cultural, natural, and custom background also gives an influence to the style, character, and the themes of the stories. For example, the setting such as tropical jungle, the character such as the elephant, tiger are almost impossible to find in European based traditional stories, on contrary, the setting such as snow, pines forest, the wolf as the character are not known in the traditional stories in Asia, including the traditional stories in Madura Island, Indonesia. Then, the themes are also the unique things when these two different traditional stories are compared. The choice of the themes is dealt with the social history of each society. The comparison of two different backgrounds of societies, Czech and Madura Island consequently lead the better understanding of two different characteristics in the traditional stories from both of societies.

The history of Czech cannot separate with the history of Bohemia and Moravia. Its history started from the Great Moravia in 9th century then the flourishing of Bohemia State in 10th century. There are two main dynasties in Bohemia and Moravia, first is the dynasty house of premyslovecs and the dynasty of house of Luxembourg. The first dynasty started when the sovereign of Bohemia tribe, princess Libuse married with Premysl, then their son, Prince Borivoj became the ruler of Bohemia in the 9th Century and he built Prague as the center of Bohemia power. He is the grandfather of Prince Wenceslas, the patron saint in Czech history. In 1212, under 
the ruler of Prince Premysl Otakar I, Bohemia became the kingdom. Then, when King Premysl Otakar II reigned as the king in 13th Century, Bohemia was the great kingdom. Its area was stretched from Silesia to Adriatic coast. The dynasty of Premyslovecs was declined when there is no male line, then, it was replaced by another dynasty when Eliska the sister of the last Premyslovecs ruler married with John of Luxembourg. It was the beginning of Luxembourg dynasty. The flourishing moment for this dynasty was happened in 14th Century when Charles IV became the King of Bohemia in 1346. In his ruling era, he founded the University, today known as Charles University, developed Prague Castle and new town in Prague; he also erected the bridge across Vltalva River. After the Moravia and Bohemia influence was doomed, Czech and Slovak territory was controlled by Hasburg Empire, since 1620 under Rudolf II as a part of this empire state for centuries. In 1918, Bohemia and Moravia became an independent state, called Czechoslovakia.

Although Paganism is the origin belief, Czech culture is much influenced by the Christianity that came around 845, when fourteen Czech princes were christened in Regensberg. Then, in 863 till 864, Rotistlav the ruler of Moravia invited Cyril or Constantine and Methodius, two Byzantine monks to Moravia. Both of them wrote the religious books and ritual texts in Old Slavonic language. They were also translated many texts of the Christianity from Greek to Old Slavonic language as the Christianity guidance. At the late of the 9th century, in 1092, Paganism almost disappeared in Czech when Bratislav II of Bohemia issued the decree ordering the felling of of groves and trees sacred to Pagan ritual. Certainly, since the late of 9th century, Czech culture is dominated by Christianity and the paganism is only part in the Czech history.

Otherwise in Madura Island, Harits (2014) states that Madura is much influenced by Hinduism and Islam. Both religions have contributed to form Madura society and culture. Such acculturation gives the different perspective in Madura, for an instance, Madura society holds Islamic ceremony tightly, like the birth of prophet Muhammad SAW. They celebrate it, but the celebration is much influenced by Hinduism tradition. It is something normal, because in the past time, Madura is a part of Majapahit Empire, the center of Hindu kingdom in Indonesia. Arya Wiraraja, the first king in Madura is the ambassador from Majapahit. He gets Madura as the gift from Raden Wijaya (Majapahit founder) because he helps Raden Wijaya to beat his enemies. After Hinduism era, it changes to Islamic era, and Madura is under control of Islamic Mataram kingdom, and Mataram Kingdom was appointed Cakraningrat as the little king or the governor in Madura during this era. Surely, the acculturation is happened and consequently, it affects to other aspects of life, like literature.

Mostly literary works in Madura try to show their religious values or at least it will use the religious values as their basic themes. Madura society is the unique society that is tightly hold the social and tradition system. If talking about Madura, it does not only refer to Madurese who live in Madura Island, but also Madura people who live all over of Indonesia. Madurese who live in Madura Island is only 30\% from the whole of Madurese in Indonesia. Although, they do not live in Madura Island, they keep their own old tradition as the heritage from their predecessor. Usually they live with their communal and they bring their identity as Madurese in their new places. In special day, for an instances, the birth of Prophet Muhammad SAW, The Ascending of Prophet Muhammad SAW, EidAdha and Eid Mubarak, they will return to Madura Island to visit their family and relatives in there. They use the term "toron" (down); this term refers to the tradition of Madura people while they back to their homeland.

\subsection{Cultural Background and Its Effects to Czech and Madura Traditional Stories}

The influence of Bohemia-Moravia life and Madura life is much influenced to the traditional stories from both different countries and culture. It can be seen from the 3 stories from Czech and 3 stories from Madura Island. Bozena Nemcova 1820-1862, the woman writer from Bohemia era depicts her stories about the life of prince, princess, and the governor and their relation with an ordinary people. Nemcova tales much explores the rural life as the portrait of Bohemia and Moravia villagers' life and tradition and acquainted with her own life which is possibly noble. In Traditional stories written by Nemcova, the fairy and magical power as the heritage of Pagan life are also founded as one of its element. Such as in the Black Princess, The Clever Princess, The Golden Hill, and The Devil and Kate, all these stories account for some magical power as the setting, and also as the weapon of the main characters to accomplish her aims. In Czech stories written by Nemcova, the character usually is the ordinary people, and they get the magical power due to their hard work, effort, and struggle. The relation among the characters are unique, it usually shows the relation between the nobility and the common life. Even though the main characters are an ordinary people but the other main characters are from the noble family, and there is 
shown that the ordinary people and the noble people in the story are equal. There is no barrier for the ordinary people to marry with the princess as well as here is no barrier for the ordinary people become the high rank officer and enter to the royal life. For instances, in Black Princess and the Golden stories, the main characters are the ordinary people who get their nobility through their magical power and hard struggle. Another uniqueness of Czech stories is the theme. Because the center of theme is not the noble life or royal life, such as the king and queen life with their luxurious and glamour circumstances, but it much more emphasize on the ordinary people life and their effort and fate to reach the success. Such theme make them differ from other traditional stories from other parts of Europe, like England, French, and Dutch that are told more about the life in the palace and the beauty of kingdom.

Otherwise, for Madura tales, mostly nobility is the center of the theme and also the characters, although it can be found the traditional tales with the hard relation between the noble and an ordinary people such as Ke'lesap and Arya Menak. The primordial custom and tradition in whole Indonesia areas including Madura, makes the traditional folktales are dominated with the noble themes. JokoTole, Pottre Koneng, Bangsadcara and Ragapadmi, The Origin of Madura and Rato Ebu are the folktales that cannot separate with the history of Madura kingdom in the past time. Firstly, Madura is the Hindu kingdom, reigned by Arya Wiraraja in Sumenep but Madura was never becoming an independent kingdom, it was a part of Majapahit Empire, then as a part of Islamic Mataram kingdom. But the demarcation line between royal family and an ordinary people is hold tightly and strictly. The royal family lived in their own circle and take away from the ordinary people life. The caste system as the heritage of Hinduism gives the strong effects to the relationship between the Nobel class and the ordinary people, thus the marriage between the royal family member and the ordinary people is suggested as taboo. Though, the tradition is changed from Hindu to Islam, but this is not easy to change the belief and the Hin$\mathrm{du}$ tradition that is come to Indonesia since the 3rd Century. Hinduism had become the tradition for 10th Centuries before Islam came to Indonesia in around 14th century (Harits, 2011a).

Consequently, it affects to the culture, tradition, and custom in Indonesia, like it has been reflected in Madura folktales. The characters in Madura folktales are the prince, princess, queen, and the king, angel, and few of an ordinary people as the hero. On the other hand, the morality, religious, and toughness will be the center of themes in Madura folktales. The king, the queen, the prince and the princess are described as the holy people with their sincere attitude and behavior. Such as in Rato Ebu, the queen is as the holy queen who is her life was devoting only to God and taking away from her life in the world.

\subsection{Searching for Identity: Heritage and Education for the Posterity}

Czech fairy tales written by Bozena Nemcova, are dealt with the flourishing of the nationalism in Czech in around 17th century. It is because after the decline of Luxembourg dynasty, Bohemia and Moravia are occupied by the other country as a part of Austro-Hungarian Empire since 15th century. Czech people and also Slovak cannot use their own languages because they were dominated by the different culture, because Austria and Hungary Empire are very strong in East and Central Europe at this time. The awareness of Czech identity comes and the movement of nationalism begins. Nemcova and her husband involve with this movement, attempting to give an political awareness to the Czech women to join with the nationalist movement like her work in ZenamCeskym her first published poetry. The awareness of independent from Vienna has much inspired Nemcova to collect and write the folktales including the fairy tales. She went around the villages in Czech and Slovak to compile and explore the origin culture, custom, and stories. She intends to promote the native culture in Czech and Slovak to all of Czech and Slovak tribes as their basic identity as the nation and to give an awareness of the importance to own their identity separated from Austro-Hungary empire.

Her works of fairy tales has some uniqueness and characteristics due to her exploration of Czech and Slovak tradition and it makes them has the "Czech Taste". First, almost all of hero and heroines are an ordinary people. Secondly, the Devil and the Witch are not evil and the at last is the stepping to accomplish the aim. Her way of writing to deliver the values of the native tradition is really different and it also reflects the rural area life. It is raised the optimistic in acquainted with the nation pride, because mostly it tells the success of the ordinary people gaining their aims. In Black Princess, the main hero is the poor fisherman son, Radovid who married with the Black Princess in the underground golden palace. Radovid is only an ordinary people and his marriage with the black princess is his power of love through long steps of overwhelming struggling. After his mistake breaking his promise to the princess, he is got the punishment. Then he starts his bloody trip to accomplish his 
aim getting his happy life with the princess. He makes a trip to return to the Golden palace where the black Princess is lived. At least four steps he must pass through to find the palace. The ferry man, the giant in the island, the giant in the mountain, and the king of bird are all the characters he must be met in his journey before he comes to the palace. It shows how the difficult is the trial to reach the happiness. The next, the Black man and the dwarf in this fairy tale was representing the devil's spirit in this story. Both of them are one, but he can change into many forms. He is not totally evil character due to he promises to release his spell to the Black Princess if somebody falls in love in her. The dwarf also searches and persuades Radovid to come and recognize the Black Princess. In the end, when Radovid keeps his promise gives his love only to the Black Princess, the dwarf or the Witch also keep his promise to release her from her spell, and he also wants send back both of them on the earth, even though both of them are rejected and choose to live in the underground palace.

The same motive of Nemcova fairy tales also can be shown in the Golden Hill, The Devil and Kate, and The Clever Princess. In the Golden Hill, Libor is the main character of the story and he is only the gardener and the son of the poor old widow. As the ordinary people, he also must undergo the bloody and tiring trip to accomplish his aim to marry with the swan princess that he loved so much, Cekanka. His inquiry process to three housekeeper siblings sends him to arrive in the Golden Hill. Here Cekanka mother as the witch is depicted as the evil character. She is not devil, but she is the evil witch who tries to kill Libor. But, Cekanka saves Libor and she is married him. Meanwhile, in The Devil and Kate, the steps of accomplishing the aim is not the long trip, but it refers to the effort of the shepherd to save the two governors and the prince from the devil and the effort of the devil to release himself from Kate, an ugly girl who hold in the devil's back sticky. The characteristics of the devil is unique, he is not the evil creature due to his helping to the Shepherd. The devil helps the shepherd to get the wealth. Through his trick to cheat the governors, he can help the shepherd. He does such things, because he wants revenge the shepherd kindness releasing him from Kate. The reasons of devil to take the governors and the prince to the hell are also caused by the bad behavior and attitude of the governors and the prince who steal the people money for their own happiness. By the end, the prince has changed his bad manner and made the shepherd as his Prime Minister. The ordinary people become the high rank officer.

The next, in the Clever Princess, the hero is the Craftsman, Jirik who want married with the beautiful princess in the palace. He commits an approval with the devil for twenty years. He will get the wealth and can marry with his imagined princess, but after the twenty years is passed, the devil will come and bring him to the hell. The steps of accomplishment are carried out by Jirik wife, the clever princess to save his husband life and to keep their happiness. The devil as it has been mentioned before is not fully evil creature in Czech fairy tales. He offers three tasks to Jirik, and if he cannot do one of the tasks, he will let Jirik lives with his family happily. The Clever Princess or the queen finally is able to trick the devil by giving the unsolved task to the devil. She asks to the devil to lengthen her three pieces of hair and he cannot afford it. Finally, he gives them the letter and let them enjoying their happy life.

Unlike in Czech which is dominated by the fairy tales, the folktales in Madura are dominated by the myth and legend. The myth is much recount and explains the origin of the world and the phenomena of the nature while the legend is based on either real or supposedly real individual or their marvelous deeds (Lynch-Brown \& Tomlinson, 1999: p. 99). According to the observation, there is only one fairy tales in Madura, Aryo Menak and the rest of them are the myth and legend. The examples of myth in Madura are The Origin of Madura and The Origin of Tajungan whereas for the legend are Rato Ebu, Bangsadcara and Ragapadme and Joko Tole. During the form of folktales are myth and legend and coincidently they are the reflection of the society custom and tradition, Madura folktales are much more referred to the cultural values such as moral and religious values (Harits, 2011b). Thus, the image of the hero and heroine are always suggested as the holy people together with all their kindnesses, sincere attitude and behavior, and their great deeds for their society (Grilli, 1997).

It is almost impossible to find the hero and the heroine in Madura folktales cheating to anybody else and tricking to reach their aims. Syarifah Ambami is depicted as the woman who was devoting her life to pray and serving for God. She loves her husband, family, and people around her very much, so that she sacrifices her life for all of people. The other examples is Joko Tole, The Prince of Madura and the knight of Majapahit Empire, he is depicted as the man who has the great loyalty, patience, and toughness. He believes the kindness will be the winner. He has proved, while the king tries to prove his loyalty. He accepts the marriage, he also takes care his blind wife well and patiently. With his patience and toughness he tries to cure his wife. Finally, he gets the miracle, when on the way of his trip, he finds the fresh water in the lake, and he asks his wife to wash her face. The miracle is given by the gods because he has been passed from the test from the Gods. It is his pride to his 
blind wife. He is tough man and husband, while he accepts the marriage and never thought his wife weakness.

The only one different folktales in Madura is Aryo Menak due to its the only one fairy tales in Madura. The character, Aryo Menak, is the farmer and he is an ordinary people who married with an angel from the paradise. He also undergoes the trick and cheating by stealing the angel's shawl while she was taken a bath in the lake. Due to her missing of shawl, she cannot return to the paradise together with other angels, and married with Aryo Menak. Like other fairy tales in the world, the angel is also described to have the magical power. Otherwise, the stages of accomplishment are not told clearly because the ending of story is not totally happy ending due to the returning of the angel to the paradise. At last, Aryo Menak lived with his son on the earth, and his society was bathing with the wealth from the angel or his wife from the paradise.

\section{Conclusion}

Both Czech and Madura folktales are used to promote the native tradition and custom as the identity of their own tribe. It is functioned as the didactic media for their own posterity. The values and the messages inside the folktales could be the guidance of the children as well as the adult attitude and behavior. The hard struggle to accomplish the success, the bloody effort to gain the aim, the hard work, the loyalty, the patience, toughness and other good behaviors and attitudes from the heroes and heroines is the positive role model for the children. Besides, they also understand with their own history, custom, culture, and tradition. The borderless era will lead to the positive and the negative effects on the children including their behavior due to their environment. They tend to learn from an overt behavior from others. The engaging between children and the traditional folktales will give the enrichment and reinforcement for the children dealing with the positive values from the heroes and heroines in the traditional folktales.

\section{Acknowledgements}

Internal grant of PDF UP: From subjective implicit theories of education to teaching knowledge. The process of constitution of a cognitive framework sciences education in the national and international context IGA_PdF_ 2015_022 The phenomena of relationships between education and thinking in constructivism education.

\section{References}

Applefield, J. M., Huber, R., \& Moallem, M. (2001). Constructivism in Theory and Practice: Toward a Better Understanding. High School Journal, 84, 35-53. www.people.uncw.edu

Desforges, C. (2000). In M. Ben-Peretz, S. Brown, \& B. Moon (Eds.), Routledge International Companion to Education. London: Routledge.

Grenby, M. (2004). Children Literature. Edinburg: Edinburg University Press.

Grilli, G. (1997). Myth, Symbol, and Meaning. New York: Routledge.

Hakemulder, J. (2000). The Moral Laboratory. Amsterdam: John Benyamin Publishing. http://dx.doi.org/10.1075/upal.34

Harits, I. W. (2011a). Enhanching Writing Competence through Madura Folktales: A Case Study at Trunojoyo University Madura. Nobel, 2, 23-37.

Harits, I. W. (2011b). The Social Position and Typology of Madurese Women in Madura Folktales. Atavisme, 14, $194-202$.

Horihan, M. (1997). Deconstructing the Hero. London: Routledge.

Hunt, P. (Ed.) (2003). Literature for Children. London: Routledge. http://dx.doi.org/10.4324/9780203167878

Husen, T., \& Postlethweite, T. N. (1989). The International Encyclopedia of Education (Vol. 1). New York: Pergamon Press.

Juvova, A., Chudy, S., Neumeister, P., Plischke, J., \& Kvintova, J. (2014). Reflection of Constructivist Theories in Current Educational Practice (pp. 1-8). UP Olomouc: VoiceS project.

Lynch-Brown, C., \& Tomlinson, C. M. (1999). Essential of Children Literature. Boston, MA: Allyn and Bacon.

Marczyk, G., de Matteo, D., \& Festinger, D. (2005). Essential of Research Design and Methodology. Hoboken, NJ: John Wiley and Sons Inc.

Meautia, C. I. (2009). Pengabaian Pengajaran Local Wisdom Dalam Pembelajaran Bahasa. In Prosiding Seminar Nasional 1 Universitas Trunojoyo Madura (pp. 114-122). Madura: Jaudar Press.

Pressley, M., \& McCormick, C. B. (1997). Advanced Educational Psychology. New York: Harper Collins.

Reeves, S., Kuper, A., \& Hodges, B. D. (2008). Qualitative Research Methodologies: Ethnography. British Medical Journal, 337, a1020. http://dx.doi.org/10.1136/bmj.a1020 
I. W. Harits et al.

www.britskelisty.com

www.encyclopedia.com

www.livingprague.com

$\underline{\text { www.traveliana.com }}$ 